\title{
Experimental poisoning by Baccharis megapotamica var. weirii in buffalo ${ }^{1}$
}

\author{
José C. Oliveira-Filho ${ }^{2}$, Priscila M.S. Carmo ${ }^{2}$, Anita Iversen ${ }^{3}$, Kristian F. Nielsen ${ }^{3}$ \\ and Claudio S.L. Barros ${ }^{*}$
}

\begin{abstract}
Oliveira-Filho J.C., Carmo P.M.S., Iversen A., Nielsen K.F. \& Barros C.S.L. 2012. Experimental poisoning by Baccharis megapotamica var. weirii in buffalo. Pesquisa Veterinária Brasileira 32(5):383-390. Departamento de Patologia, Universidade Federal de Santa Maria, Camobi, Santa Maria, RS 97105-900, Brazil. E-mail: claudioslbarros@uol.com.br

Five male 6-8 month-old Murrah buffalo calves were orally dosed with the fresh aerial parts of Baccharis megapotamica var. weirii at doses of 1, 3, 4, 5 and $10 \mathrm{~g} / \mathrm{kg}$ body weight (bw) ( 1-10mg macrocyclic trichothecenes $/ \mathrm{kg} / \mathrm{bw})$. The B. megapotamica used for the experiment was harvested on a farm where a recent spontaneous outbreak of poisoning caused by such plant had occurred. Clinical signs appeared 4-20 hours and 4 buffaloes died 18-49 hours after the ingestion of the plant. Clinical signs were apathy, anorexia, and watery diarrhea, fever, colic, drooling, muscle tremors, restlessness, laborious breathing and ruminal atony, and dehydration. The most consistent gross findings were restricted to the gastrointestinal (GI) tract consisted of varying degrees of edema and reddening of the mucosa of the forestomach. Histopathological findings consisted of varying degrees of necrosis of the epithelial lining of the forestomach and of lymphocytes within lymphoid organs and aggregates. Fibrin thrombi were consistently found in sub-mucosal vessels of the forestomach and in the lumen of hepatic sinusoids. It is suggested that dehydration, septicemia and disseminated intravascular coagulation participate in the pathogenesis of the intoxication and play a role as a cause of death. A subsample of B. megapotamica var. weirii was frozen-dried and ground and analyzed using UHPLC (Ultra High Performance Liquid Chromatography) with high resolution Time of Flight mass spectrometry and tandem mass spectrometry, it was shown that the plant material contained at least 51 different macrocyclic trichothecenes at a total level of $1.1-1.2 \mathrm{mg} / \mathrm{g}$. About $15-20 \%$ of the total trichothecenes contents was found to be monosaccharide conjugates, with two thirds of these being glucose conjugates and one third constituted by six aldopentose conjugates (probably xylose), which has never been reported in the literature.
\end{abstract}

INDEX TERMS: Poisonous plants, Baccharis megapotamica, buffalo, experimental plant poisoning, necrosis in forestomach, lymphoid tissue necrosis, macrocyclic trichothecenes, chemical analysis.

\footnotetext{
${ }^{1}$ Received on December 12, 2011.

Accepted for publication on December 29, 2011.

Part of the Doctoral Thesis of the senior author. Part of this study was carried out in the Centro de Ciências e Tecnologia Rural, of the Federal University of Campina Grande, Patos, Paraíba. During a 12-month fellowship granted to the first author by the Program on Academic collaboration (PROCAD-NF) from CAPES. And the costs of the present publication were covered by the same source.

${ }^{2}$ Post-Graduate Program in Veterinary Medicine, Major in Veterinary Pathology, Centro de Ciências Rurais (CCR), Universidade Federal de Santa Maria (UFSM), Camobi, Santa Maria, RS 97105-900, Brasil.

${ }^{3}$ Center for Microbial Biotechnology, Institute for Systems Biology, Technical University of Denmark, Søltofts Plads, Building 221, DK-2800 Kgs. Lyngby, Denmark.

${ }^{4}$ Laboratório de Patologia Veterinária, Departamento de Patologia, Centro de Ciências da Saúde, UFSM, Santa Maria, RS 97105-900. Pesquisador 1A do CNPq. *Corresponding author: claudioslbarros@uol.com.br
}

RESUMO.- [Intoxicação experimental por Baccharis megapotamica var. weirii em búfalos.] As partes aéreas verdes de Baccharis megapotamica var. weirii foram administradas oralmente a cinco búfalos da raça Murrah de 6-8 meses de idade nas doses de $1,3,4,5$ e $10 \mathrm{~g} / \mathrm{kg}$ de peso corporal (pc) ( 1-10mg de tricotecenos macrocíclicos/kg/ pc). A planta usada no experimento foi colhida numa fazenda onde um surto recente de intoxicação espontânea por essa planta havia ocorrido. Nos búfalos deste experimento, os sinais clínicos apareceram 4-20 horas e 4 búfalos morreram 18-49 horas após a ingestão da planta. Os sinais clínicos consistiram de apatia, anorexia, diarreia aquosa, febre, cólica, salivação, tremores musculares, inquietação, respiração laboriosa, atonia ruminal e desidratação. Os achados 
macroscópicos mais consistentes estavam restritos ao trato gastrointestinal (GI) e consistiram de graus variados de edema e avermelhamento da mucosa dos pré-estômagos. Os achados histopatológicos consistiam de vários graus de necrose do epitélio de revestimento dos pré-estômagos e de linfócitos em agregados e órgãos linfoides. Trombos de fibrina foram consistentemente encontrados nos vasos da submucosa dos pré-estômagos e na luz dos sinusoides hepáticos. É sugerido que desidratação, septicemia e coagulação intravascular disseminada participem da patogênese da intoxicação e sejam fatores responsáveis pela morte dos animais afetados pela intoxicação. Uma subamostra de B. megapotamica var. weirii foi congelada a seco, moída e analisada usando UHPLC (Cromatografia Líquida de Ultra Alta Performance) com espectrometria de tempo-de-vôo de alta resolução e espectrometria de massa em tandem. Foi demonstrado que o material de planta analisado continha pelo menos 51 tricotecenos macrocíclicos diferentes num nível total de 1,1-1,2mg/g. Cerca de $15-20 \%$ do conteúdo total de tricotecenos eram conjugados de monossacarídeos, sendo dois terços desses, conjugados de glicose e um terço constituídos por seis conjugados de aldopentose (provavelmente xilose), o que nunca tinha sido antes relatado na literatura.

TERMOS DE INDEXAÇÃO: Plantas tóxicas, Baccharis megapotamica, búfalo, intoxicação experimental por planta, necrose dos pré-estômagos, necrose do tecido linfoide, tricotecenos macrocíclicos, análise química.

\section{INTRODUCTION}

The Baccharis genus (Asteraceae: tribe Asteraceae) includes nearly 500 species. All are found in the New World with the exception of B. halimifolia, which was introduced into Australia from the United States (Jarvis et al. 1991). This species is suspected of poisoning cattle in both countries (Everist 1981) and proved toxic when administered experimentally to chicks (Duncan et al. 1957). B. glomerulifolia, another North American species, was experimentally toxic to mice and chicks (Duncan et al. 1957), and B. pteronioides has been associated with cattle poisoning in the southwestern United States (Marsh et al. 1920, Stegelmeier et al. 2009). B. pteronioides toxicosis was produced in hamsters dosed with 100-200mg of the plant (Stegelmeier et al. 2009). B. artemisioides causes disease in cattle in a restricted zone of Argentina, northwest of Buenos Aires and southeast of Cordoba (Rizzo et al. 1997).

Nearly 120 species of Baccharis have been recorded in Brazil; of those, only $B$. coridifolia (Tokarnia \& Döbereiner 1975, Barros 1998) and B. Megapotamica (Tokarnia et al. 1992, Driemeier et al. 2000, Pedroso et al. 2010) have been proven to be toxic to livestock. Both B. megapotamica and $B$. coridifolia are found in southern Brazil, but they occupy different habitats; $B$. megapotamica is found in marshy areas (Tokarnia et al. 1992) whereas B. coridifolia grows in pastureland (Barros 1998). Two varieties of B. megapotamica with essentially the same distribution and toxic effects on livestock are known, namely $B$. megapotamica var. megapotamica and B. megapotamica var. weirii (Tokarnia et al. 1992).
B. coridifolia and the two varieties of B. megapotamica cause a severe acute poisoning in livestock characterized by degeneration and necrosis of the epithelial lining of gastrointestinal tract and necrosis of lymphocytes in lymph nodes, spleen, tonsils, and several lymphoid aggregates (Tokarnia \& Döbereiner 1975, Tokarnia et al. 1992, Barros 1998, Varaschin et. al. 1998, Varaschin \& Alessi 2003). B. megapotamica (Kupchan et al. 1977) B. coridifolia, (Busam \& Habermehl 1982, Habermehl et al.1985) and B. artemisioides (Rizzo et al. 1997) contain a series of potent cytotoxic agents belonging to the highly cytotoxic macrocyclic trichothecene complex previously believed to be produced only by fungi (Jarvis et al. 1996). In the case of B. megapotamica, the macrocyclic trichothecenes accumulate in the plant as baccharinoids ( B1, B2, B3, B4 etc.), roridins including their glycosides, and miotoxins (Jarvis et al. 1996). To date, no macrocyclic trichothecenes have been detected in B. halimifolia, B. pteronioides, or B. glomerulifolia.

Spontaneous poisoning by $B$. coridifolia occurs frequently in cattle (Rissi et al. 2005) occasionally in sheep (Rozza et al. 2006) and rarely in horses (Alda et al. 2009) Isolated reports of spontaneous outbreaks involving B. megapotamica var. weirii have been reported in cattle (Driemeier et al. 2000) sheep (Pedroso et al. 2010) and buffaloes (Oliveira-Filho et al. 2011). There are also some anecdotal accounts of spontaneous toxicosis by B. megapotamica var. weirii in cattle. Typically, the toxicosis in livestock occurs when naïve animals raised in areas free of Baccharis spp. are transferred to pastures infested by the plant. The susceptibility increases considerably if the animals are subjected to such stress factors as fatigue, hunger, or thirst (Barros 1998). Interestingly, cattle that are raised in pastures where Baccharis spp. exist will graze it very rarely if ever, although in the case of $B$. megapotamica var. weirii there are anecdotal accounts that particularly hungry cattle familiar with the plant, may, on occasion, ingest it and get poisoned.

A recent outbreak of $B$. megapotamica var. weirii poisoning in buffalo diagnosed at our laboratory (Oliveira-Filho et al. 2011) prompted the undertaking of the current experimental study to determine the clinical and pathological aspects of the B. megapotamica var. weirii poisoning in buffaloes, the pathogenesis of the toxicosis and the toxic principles involved in this plant.

\section{MATERIALS AND METHODS}

Five male 6-8-month-old, 122-143 kg Murrah buffaloes identified by numerals 1-5 were used in the experiment. Each buffalo was force-fed orally with a single dose of fresh Baccharis megapotamica var. weirii respectively at doses of $1,3,4,5$ and $10 \mathrm{~g} /$ body weight (bw) (Table 1). Only the top $10 \mathrm{~cm}$ of the aerial parts of the plant were fed to the buffaloes. Just before the administration of the plant and every four hour after the dosing, the buffaloes were clinically evaluated for the following parameters: respiratory and cardiac rates, rectal temperature, time of capillary filling, ruminal movements, posture, ambulation and behavioral changes. During the whole duration of the experiment the buffalo were kept in a fenced paddock and were offered Tifton hay and water ad libitum.

For the experiment, specimens of B. megapotamica var. weirii were harvest in a farm in the municipality of Diler- 
Table 1. Experimental poisoning by Baccharis megapotamica var. weirii in buffalo

\begin{tabular}{cccccc}
\hline Buffalo & $\begin{array}{c}\text { Weight } \\
(\mathrm{kg})\end{array}$ & $\begin{array}{c}\text { Dose of plant } \\
\text { administered } \\
(\mathrm{g} / \mathrm{kg})^{\mathrm{a}}\end{array}$ & $\begin{array}{c}\text { Time spent in the } \\
\text { administration of } \\
\text { the plant }\end{array}$ & $\begin{array}{c}\text { Severity of } \\
\text { clinical signs }\end{array}$ & $\begin{array}{c}\text { Time between the ter- } \\
\text { minus of the ingestion } \\
\text { of the plant and death }\end{array}$ \\
\hline 1 & 143 & $10 \mathrm{~g}$ & $2 \mathrm{~h} 15 \mathrm{~min}$ & $+_{++}^{\mathrm{b}}$ & $18 \mathrm{~h} 30 \mathrm{~min}$ \\
2 & 132 & $5 \mathrm{~g}$ & $55 \mathrm{~min}$ & +++ & $19 \mathrm{~h} 45 \mathrm{~min}$ \\
3 & 135 & $4 \mathrm{~g}$ & $1 \mathrm{~h} 05 \mathrm{~min}$ & +++ & $49 \mathrm{~h} 5 \mathrm{~min}$ \\
4 & 122 & $3 \mathrm{~g}$ & $1 \mathrm{~h} 33 \mathrm{~min}$ & +++ & $21 \mathrm{~h} 40 \mathrm{~min}$ \\
5 & 146 & $1 \mathrm{~g}$ & $30 \mathrm{~min}$ & $+^{\mathrm{c}}$ & Survived
\end{tabular}

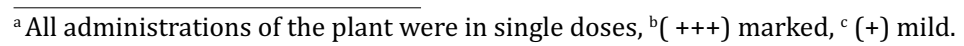

mando de Aguiar, state of Rio Grande do Sul, Brazil, from where a spontaneous outbreak of $B$. megapotamica var. weirii was recently reported (Oliveira-Filho et al. 2011) S. $^{5}$ The harvest plant was kept at $4^{\circ} \mathrm{C}$ until fed to the experimental buffalo; the time elapsed from the harvesting and the feeding was never longer than 48 hours.

For chemical analysis plant material was frozen-dried and ground to a fine powder using a domestic coffee mill; then $0.50 \pm 0.01 \mathrm{~g}$ material was distributed into $15 \mathrm{ml}$ Falcon tubes, $6.5 \mathrm{ml} 55 \% \mathrm{MeOH}$ was added and the tubes placed on a shaking table for $4 \mathrm{hr}$. Tubes were then centrifuged at $7000 \mathrm{~g}$ for 3 minutes and $4.5 \mathrm{ml}$ of the supernatant transferred to new tubes and evaporated to dryness with $\mathrm{N}_{2}$. Samples were then redissolved in 50\% methanol and filtered through a $0.45 \mu \mathrm{m}$ teflon syringe filter into an autosampler vial.

Quantification was done in spiked matrix, by spiking ground freeze dried material with $75 \mu \mathrm{l}$ methanol solution containing roridin A (leaving to dry for $2 \mathrm{hr}$ ) to a final concentration of $375,188,94,47,23,12,5.9,2.9,1.5,0.73$, and $0.37 \mathrm{mg} / \mathrm{kg}$, as well as 3 un-spiked matrix samples.

A few extracts (from 2-3g material) were further extracted and purified by redissolving the extract in dichloromethane and subsequently passing the extract through a polyethylene imine silica column (Jarvis 1992, Jarvis et al. 1996). The column was eluted with dichloromethane (fraction 1) and methanol (fraction 2). These were both evaporated to dryness with $\mathrm{N}_{2}$ and redissolved as above.

Samples were analysed by Ultra High Performance Liquid chromatography-high resolution mass spectrometry (UHPLC-HRMS) on a maXis G3 quadrupole time of flight mass spectrometer (Bruker Daltonics, Bremen, Germany) equipped with an electrospray (ESI) source. The MS was connected to an Ultimate 3000 UHPLC system (Dionex, Sunnyvale, CA). Separation of $1 \mu \mathrm{l}$ samples were performed at $40^{\circ} \mathrm{C}$ on a $100 \mathrm{~mm} \times 2.1 \mathrm{~mm}$ ID, $2.6 \mu \mathrm{m}$ Kinetex $\mathrm{C}_{18}$ column (Phenomenex, Torrance, CA) using a linear water-acetonitrile gradient (both buffered with $20 \mathrm{mM}$ formic acid) at a flow of $0.5 \mathrm{~mL} / \mathrm{min}$ starting from $20 \%$ acetonitrile and increased to $65 \%$ in $10 \%$ minutes, then 1 min to $100 \%$, keeping this 2 min, keeping this for 3 minutes. HRMS was performed in $\mathrm{ESI}^{+}$with a data acquisition range of 10 scans per $\mathrm{sec}$ at $\mathrm{m} / \mathrm{z}$ 100-1000. The MS was calibrated using sodium formate automatically infused prior to each analytical run,

\footnotetext{
${ }^{5}$ Identification of the plant as Baccharis megapotamica var. weirii was made by Prof. José Newton Marchiori from the Departmento de Ciências Florestais, Centro de Ciências Rurais, Federal University of Santa Maria, Brazil.
}

this provided a mass accuracy of less than $1.5 \mathrm{ppm}$ in MS mode. Trichothecenes were detected as extracted ion chromatograms $( \pm 0.002 \mathrm{Da})$ of the $[\mathrm{M}+\mathrm{H}]^{+}$ion with $\left[\mathrm{M}+\mathrm{NH}_{4}\right]^{+}$ and $[\mathrm{M}+\mathrm{Na}]^{+}$used as qualifiers. The monosaccharide conjugated trichothecenes were detected as $\left[\mathrm{M}+\mathrm{NH}_{4}\right]^{+}$and $[\mathrm{M}+\mathrm{Na}]^{+}$ions. Tandem experiments were conducted on the $[\mathrm{M}+\mathrm{H}]^{+}$and $\left[\mathrm{M}+\mathrm{NH}_{4}\right]^{+}$ions with a collision energy of 20-30 $\mathrm{eV}$ and nitrogen as collision gas. Reference standards of trichodermin, roridins $\mathrm{E},-\mathrm{H}$, and $\mathrm{L}-2$, verrucarins $\mathrm{J},-\mathrm{A}$ and $-\mathrm{H}$, satratoxins $\mathrm{G},-\mathrm{H}$, and iso-F, trichoverrols $A$ and $B$, as well as trichoverrins $A$ and $B$ were all co-analyzed with the samples. Extracted ion chromatograms were constructed for all trichothecenes known from Baccharis and Myrothecium species as noted in Antibase2010 (Nielsen et al. 2011), as well as for baccharinoids, miophytocens, miotoxins and trichothecenes (Jarvis et al. 1988, 1991, 1996, Jarvis 1992) including several glucose conjugated trichothecenes.

Blood Samples were collected from the jugular vein of the experimental buffalo for complete blood count, proteinogram, and determination of seric activity of aspartate transaminase (AST), and determination of fibrin degradation products (FDPs). Hemoculture were performed in blood samples drawn aseptically from Buffalo 1 and 3 after they presented overt clinical signs of intoxication.

All buffalo were necropsied and several tissue samples were collected during the necropsies and fixed in $10 \%$ buffered formalin, processed routinely for histopathology and stained by hematoxilin and eosin. Selected samples of liver and kidney were stained by Fraser-Lendrum method for the demonstration of fibrin; in this method fibrin, keratin, and some cytoplasmic granules appear red, erythrocytes appear orange, and collagen appears green.

For histopathological evaluation of the epithelial changes in the gastrointestinal tract fragments of the following organs were sampled: ruminoreticulum (dorsal sac, ventral sac, reticular fold, cranial pillar, caudoventral blind sac, and caudodorsal blind sac), omasum, abomasum, duodenum, jejunum, ileum, proximal colon, spiral colon, cecum, and rectum. For histopathological evaluation of the lymphoid system fragments of following organ/tissues were sampled: tonsils, spleen, gut associated lymphoid tissue, bronchial associated lymphoid tissue; and 10 lymph nodes (prescapular, axilar, mandibular, popliteal, gastric, jejunal, hepatic, bronchial, internal iliac, and renal).

\section{RESULTS}

Chemical analysis of the plant revealed 51 one different major macrocyclic trichothecenes; the major peaks are 
shown in Figure 1. All five treated buffalo showed clinical signs and four of them died. Data regarding the time elapsed from the ingestion of the plant, the severity of clinical signs showed by each buffalo and the time elapsed between

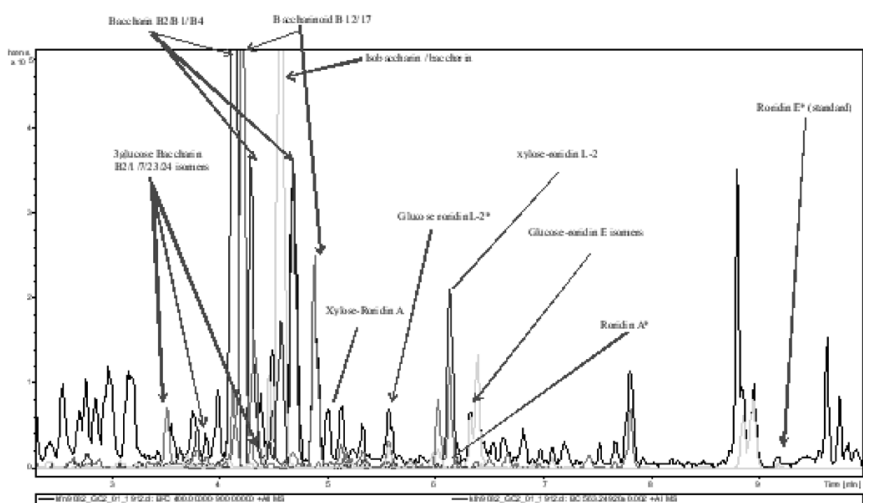

Fig.1. Chemical analysis of the plant Baccharis megapotamica var. weirii used in the experiment. Base peak chromatogram (bla$\mathrm{ck} \mathrm{m} / \mathrm{z}$ 400-900) overlaid with extracted ion chromatogra$\mathrm{ms}$ of the $[\mathrm{M}+\mathrm{H}]^{+}$ion the macrocyclic trichothecenes and the $\left[\mathrm{M}+\mathrm{NH}_{4}\right]^{+}$of the glycosylated/xylanated derivatives, showing that in this crude extract most the major peaks in this time frame are macrocyclic trichothecenes.

ingestion of the plant and death of the animal are on Table 1. The onset of clinical signs varied form 4 hours (Buffalo 1) up to 20 hours (Buffalo 5) after the ingestion of the plant. The time elapsed from the ingestion of the plant to the death of the animal varied from 18 hours and 30 minutes $(\mathrm{Bu}-$ ffalo 1) to 49 hours and 5 minutes (Buffalo 3).

The first observed clinical signs were apathy, anorexia, and watery profuse diarrhea (Fig.2). Fever was observed in all experimental buffalo, except Buffalo 5, and reached $40.9^{\circ} \mathrm{C}$ in Buffalo 1 . The clinical signs evolved rapidly to colic (tenesmus), drooling (Fig.3), muscle tremors, restlessness, and loss of strength of ruminal movements eventually terminating in complete ruminal atony, laborious breathing, and dehydration, seen as sunken eyes in the orbit pockets and loss of normal cutaneous turgidity. Tachycardia and in-

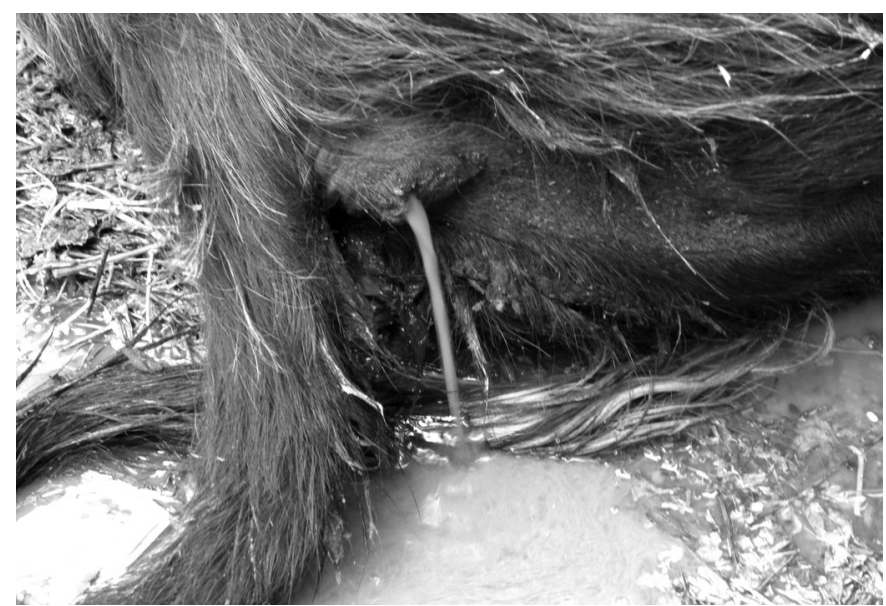

Fig.2. Buffalo 2, affected in the experimental poisoning by Baccharis megapotamica var. weirii. Watery profuse diarrhea like the one illustrated here was one of the first clinical signs observed in the affected buffalo. creased time of capillary filling were also observed. With the exception of Buffalo 5, the capillary filling time was up to 5 minutes. Of the 5 buffaloes fed B. megapotamica var. weirii, only Buffalo 5 which was fed $1 \mathrm{~g} / \mathrm{kg} / \mathrm{bw}$ of the plant, survived after running a short clinical course consisting of moderate liquid diarrhea and apathy. After 48 hours of the onset of the clinical signs this buffalo recovered and was euthanized in the following day for necropsy.

The most consistent gross findings were restricted to the gastrointestinal (GI) tract and consisted of varying degrees of edema and reddening of the mucosa of the forestomachs especially of the rumen (Fig.4) and reticulum (Fig.5). Mucosal reddening of the rumen was more intense in the cranial pillar ( 3 out of 5 buffalo examined), ruminal antrum (3/5), coronary pillar (1/5) and dorsal sac (1/5). Marked edema was observed in the reticulo-ruminal fold $(3 / 5)$ and omasum (1/5). Petechiae and paint-brush hemorrhages were observed, mainly in the dorsal sac $(3 / 4$ buffalo).

Varying sized recent ulcers were observed in the abomasum of Buffalo 1 ad 3. In all the four buffalo that died spontaneously diffuse reddening was observed in the mucosa of the duodenum, jejunum, ileum, and cecum. In this latter viscus dark-red fetid content was found. Additional, in Buffalo 2 and 4, similar reddening was observed in the mucosa of spiral colon. Linear ulcers were observed in the distal third of the esophagus in Buffalo 4. Buffalo 2-4 had enlarged gastric and jejunal lymph nodes which were red and juice to the cut surface.

Histopathological findings in the forestomach consisted of varying degrees of necrosis of the epithelial lining. This variation occurred from animal to animal and even within the same animal. In some instances only the basal layer was affected (Fig.6), in others both the basal and squamous layer were affect and still in other the whole thickness of the ruminal squamous stratified epithelium was affected (Fig.7). These changes were associated with hyperemia, edema, and inflammatory infiltrate predominantly neutrophilic, bacterial aggregates in the submucosa. Bacterial ag-

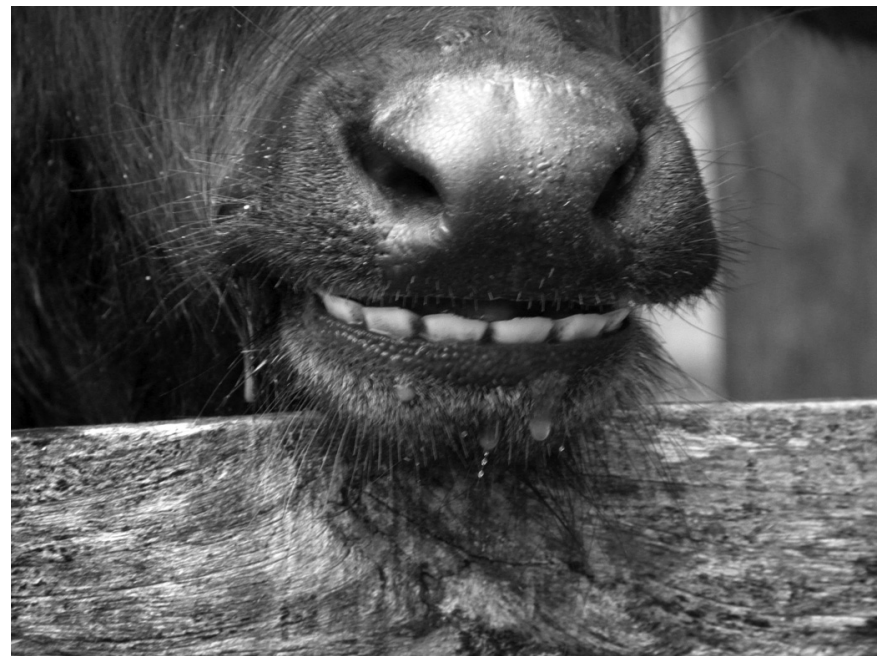

Fig.3. Drooling in Buffalo 3 experimentally poisoned by Baccharis megapotamica var. weirii. 

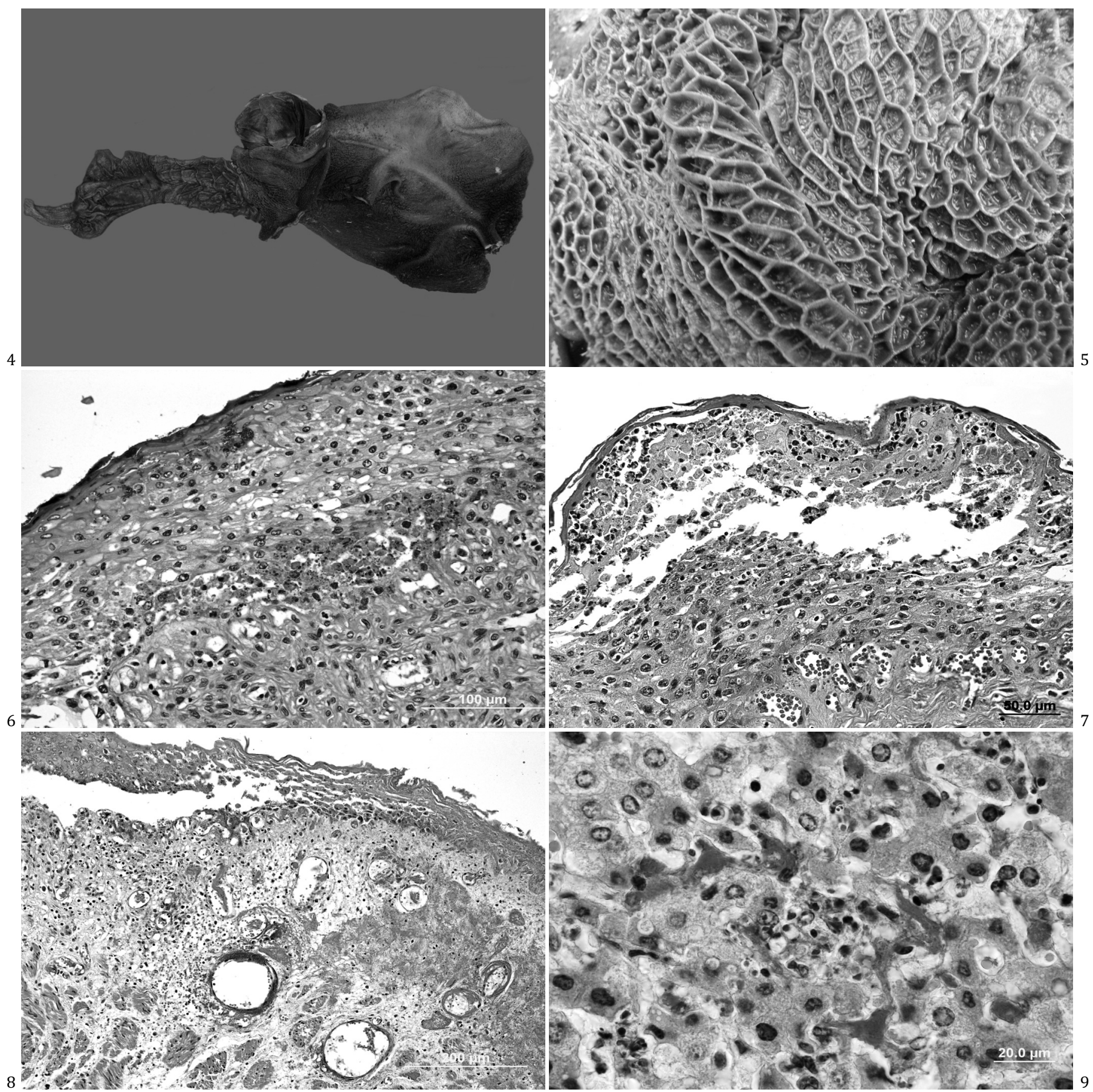

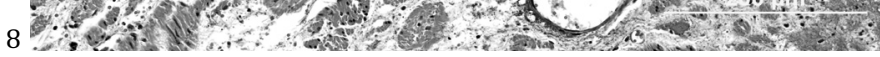

Fig.4. Reddening of the mucosa of the forestomach from Buffalo 3 experimentally poisoned by Baccharis megapotamica var. weirii.

Fig.6. Necrosis of the basal layer of the lining squamous stratified of the ventral sac of the rumen of Buffalo 2 experimentally poisoned by Baccharis megapotamica var. weirii. HE, obj.40x.

Fig.8. Reticular fold of Buffalo 4 experimentally poisoned by Baccharis megapotamica var. weirii. Bacterial aggregates can be observed surrounding blood vessels of the submucosa which is marked edematous. HE, obj.20x.

gregates were found over the forestomach epithelial deprived submucosa and in one case surrounding blood vessels of the submucosa (Fig.8). Fibrin thrombi were consistently
Fig.5. Reddening of the mucosa of the reticulum from Buffalo 1 experimentally poisoned by Baccharis megapotamica var. weirii.

Fig.7. Necrosis of the full thickness of the ruminal squamous stratified epithelium of the dorsal sac of the rumen of a Buffalo 3 experimentally poisoned by Baccharis megapotamica var. weirii. HE, obj.40x.

Fig.9. Histopathology of the liver of Buffalo 1 experimentally poisoned by Baccharis megapotamica var. weirii. Fibrin thrombi are observed in the lumen of hepatic sinusoids. Fibrin are stained red, erythrocytes appear orange, and scant collagen appears green. Fraser-Lendrum stain, obj.40x.

found in submucosal vessels of the forestomach and in the lumen of hepatic sinusoids. These thrombi were positive for fibrin by the Fraser-Lendrum method (Fig.9). 
The necrosis in the epithelial lining of the forestomach were more intense in the following order of decreasing intensity: reticular fold, ruminal ventral sac, ruminal caudoventral blind sac, ruminal cranial pillar, reticulum, caudodorsal blind sac, dorsal sac, and omasum. In reticular fold of one animal (Buffalo 1) there was also necrosis of the smooth muscle layer beneath the areas of epithelial necrosis. Mild necrosis (Buffalo 2 and 3) were observed in the parietal cells of the abomasal mucosa.

Hepatic necrosis was observed in the four buffalos that died due to the intoxication. It consisted of multifocal individual foci of necrosis or individual hepatocelular necrosis. In on animal (Buffalo 3) the necrosis was more prominent in the hepatocytes adjacent to the portal triads. In two cases (Buffalo 1 and 3) diffuse moderate cytoplasmic vacuolization was observed.

Necrosis of lymphocytes (Fig.10) was observed in all four buffalo dying from the intoxication and in all lymphoid organ/tissues sampled. The intensity of lymphocyte necrosis was dose dependent and varied depending of the type o lymphoid tissue examined, being more prominent in the gut associated lymphoid aggregates and in the jejunal and mesenteric lymph nodes.

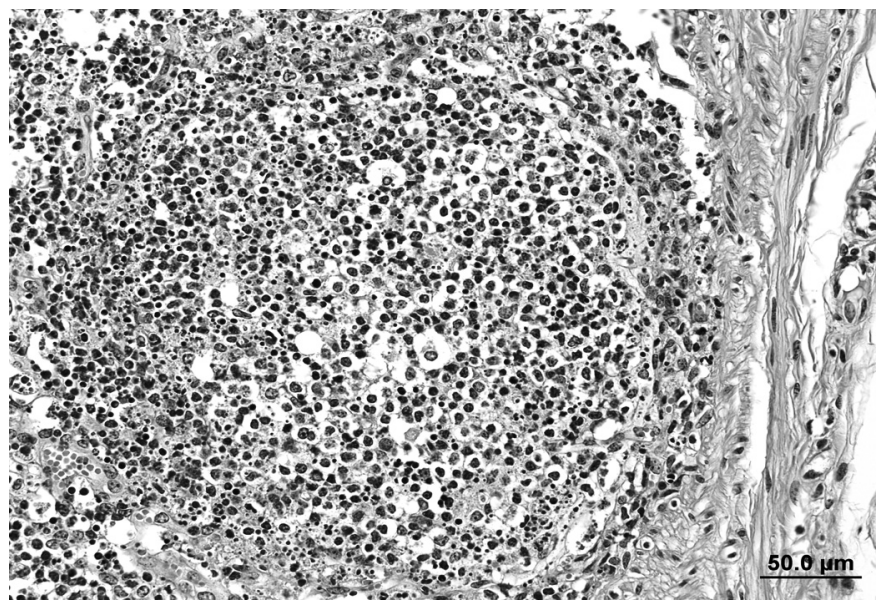

Fig.10. Histopathology showing necrosis of lymphoid lymphocytes in follicles of the lymphoid tissue in experimentally poisoning by Baccharis megapotamica var. weirii in buffalo. (A) Internal iliac lymph node of Buffalo 3. HE, obj.40x. (B) Tonsil of Buffalo 2. HE, obj.20x.

\section{DISCUSSION}

The clinical signs, clinical course, gross findings and histopathology observed in the buffalo of the current study are similar to those described in the naturally occurring Baccharis megapotamica var. weirii poisoning by in buffalo (Oliveira-Filho et al. 2011) in cattle (Driemeier et al. 2000) and sheep (Pedroso et al. 2010) and the experimental intoxication in cattle with this plant species (Tokarnia et al. 1992). The lesions are also similar to those produced by B. coridifolia in cattle (Tokarnia \& Döbereiner 1975, Barros 1998, Rissi et al. 2005) and sheep (Rozza et al. 2006). Mild intoxication was induced by a dose as small as $1 \mathrm{~g} / \mathrm{kg} / \mathrm{bw}$; however the smallest lethal dose of tested dose was $3 \mathrm{~g} / \mathrm{kg} /$ bw. This indicates that buffalo are somewhat more resis- tant to poisoning by B. megapotamica var. weirii than cattle (Bos taurus) since an oral dose of $1 \mathrm{~g} / \mathrm{kg} / \mathrm{bw}$ of this plant was lethal to bovine (Tokarnia et al. 1992).

The primary target organs in this poisoning are those of GI, especially the forestomach and the lesions are grossly characterized by reddening of the mucosal surface of these gastric compartments and submucosal edema. Characteristic histopathology includes necroses of the epithelial lining of the forestomach and to a lesser extent abomasum and intestines and necrosis of lymphocytes in lymphoid organs and lymphoid aggregates. These lesions are in accordance with the described fort the action of macrocyclic trichothecenes (Jarvis et al 1996, Varaschin et al. 1998, Varaschin \& Alessi 2003).

The pathogenesis and cause of death in Baccharis spp. in livestock was never completely resolved (Barros 1998, Rissi et al. 2005). It was suggested that dehydration, electrolyte imbalance and septicemia stemming from bacterial invasion through breakdowns in necrotic ruminal epithelium (Rissi et al. 2005) and disseminated vascular coagulation (Stegelmeier et al. 2009) could play a part. Data from the current experiment suggest that several of these mechanisms of disease production could act concomitantly or in sequence in the pathogenesis and cause of death of buffalo experimentally poisoned by $B$. megapotamica var. weirii. Dehydration was clearly a participante as judged by the hemoconcentration as demonstrated in Table 2 by radi and marked elevation in the packed cell volumes and total protein concentration in the serum. These are classical signs of dehydration (Smith and \& Magdesian 2002, Fettman 2006) and were not observed only in the one buffalo (Buffalo 5) which developed just a mild form o intoxication and survived.

Evidences of disseminated intravascular coagulation (DIC), a serious manifestation of abnormal coagulation (Morris 2002) was observed in all experimental animals excepting Buffalo 5. This was reflected in the sharp increase in fibrin degradation products which were detected in the serum of the four buffaloes that died. DIC is a severe break down in the hemodynamic homeostasis caused by the generation of excess thrombin. There are many causes, inducing diffuse vascular damage which results in exposure of blood to tissue factor (Mosier 2011). In the case of the four buffalo that died it was possible to detect thrombi formation in the liver by the method of Fraser-Lendrum and those are associated with foci of liver necrosis; thus generation of tissue factor in response to

Table 2. Laboratory data from blood of five buffalo poisoned by Baccharis megapotamica var. weirii in buffalo

\begin{tabular}{|c|c|c|c|c|c|c|c|c|}
\hline \multirow[t]{2}{*}{ Buffalo } & \multicolumn{2}{|c|}{$\mathrm{PCV}^{\mathrm{a}}$} & \multicolumn{2}{|c|}{ Total plasma protein } & \multicolumn{2}{|c|}{$\mathrm{AST}^{\mathrm{b}}$} & \multicolumn{2}{|c|}{ FDPs $^{c}$} \\
\hline & $\mathrm{PE}^{\mathrm{d}}$ & $\mathrm{AE}^{\mathrm{e}}$ & PE & $\mathrm{AE}$ & $\mathrm{PE}$ & $\mathrm{AE}$ & $\mathrm{PE}$ & $\mathrm{AE}$ \\
\hline 1 & 39 & 48 & 6.5 & 8.5 & 567 & 917 & 2.211 & $>120.086$ \\
\hline 2 & 35 & 42 & 7.2 & 8.9 & 346 & 5.497 & 6.617 & $>247.365$ \\
\hline 3 & 39,5 & 54,5 & 7.1 & 7.8 & 558 & 647 & 3.796 & 9.171 \\
\hline 4 & 40 & 54 & 7.3 & 9.4 & 194 & 775 & 2.21 & $>229.461$ \\
\hline 5 & 40 & 37 & 7.5 & 7.1 & 339 & 341 & 6.592 & 4.139 \\
\hline
\end{tabular}

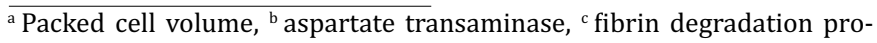
ducts, ${ }^{\mathrm{d}}$ pre-experiment sample, ${ }^{\mathrm{e}}$ sample taken after the administration of the plant a just hours before death of the buffalo. 
necrosis endothelial cells and hepatocytes is a distinct possibility, resulting in tissue factor-induced activation of extrinsic coagulation to produce thrombin. Thrombin causes platelet aggregation and activation of coagulation factors $\mathrm{V}$, VIII, and I to form fibrin, could result in the widespread microvascular clots observed in threes cases. Concurrently, the high levels of thrombin stimulate clot dissolution by binding to thrombomodulin to activate protein $\mathrm{C}$, by converting plasminogen into plasmin, and by binding to anti-thrombin III to become inactivated. The widespread nature of the coagulation response results in the consumption of these and other factors, resulting in widespread hemorrhages. Although hemorrhages were not seen in the buffalo of this study, this could be explained by the extremely short course of the disease.

Evidences of septicemia could be observed in Buffalo 1 from which bacterial culture of the blood yield non-enterococci Streptococcus Group; Bacteria of this group D can cause septicemia, among other clinical dysfunctions (Greene \& Prescott 2006). Some findings in the experimental buffalo of this study as fever and bacterial aggregates surrounding blood vessels or associated with $b$ reached ruminal epithelium are consistent with septicemia plain a role in this intoxication.

UHPLC with high resolution Time of Flight mass spectrometry proved to be a powerful technique for the analysis of the macrocyclic trichothecenes in plant extracts detecting 51 different major macrocyclic trichothecenes. The major findings were Baccharin B2/B1/4, Baccharinoid B12/B17, iso-baccharin/baccharin and the conjugate xylose-roridin L-2. Out of 14 available trichothecene standards only 2 (roridins $\mathrm{E}$ and A) could be detected in the samples. Trichothecenes found in the sample with no possibility of standard matching were identified tentatively on the basis of the MS/MS with spectra showing a fragmentation pattern (accurate mass) consistent with macrocyclic trichothecenes (Nielsen et al. 2011). These identification points included several water loss ions as well as the $\mathrm{m} / \mathrm{z} 231$ and 249 ions seen from macrocyclic trichothecenes, or m/z 229 and 247 seen in case of hydroxylation of the trichothecene skeleton. Interestingly neither verrucarins nor roridin L-2 were detected. Expressed as roridin A equivalents the 51 macrocyclic trichothecenes summed up to a total content of $1.1-1.2 \mathrm{mg} / \mathrm{g}$ which is in the same range found by Jarvis et al (1996) where $0.04-0.7 \mathrm{mg} / \mathrm{g}$ was detected. Using MS/ HRMS and in-source fragmentation, $15-20 \%$ of the total trichothecenes contents was found to be conjugated to a glucose (seen by the loses of a glucose moiety) also found by Jarvis et al. (1996) and one third constituted by 6 aldopentose conjugates, probably xylose conjugates, which was also partly confirmed by better retention of these compared to their glucose analogues. These aldopentose derivatives have to our knowledge has never been reported in the literature. All these monosaccharide derivatives could easily be identified as they only produced $\left[\mathrm{M}+\mathrm{NH}_{4}\right]^{+}$and $[\mathrm{M}+\mathrm{Na}]^{+}$ pseudomolecular ions, whereas the normal trichothecenes produced these as minor ions and $[\mathrm{M}+\mathrm{H}]^{+}$as the major ion.

The monosaccharide conjugate fraction of $15-20 \%$ fits well with the finding of Jarvis et al. (1996), and toxicology wise it is not known if these are toxic in vivo as the case for deoxynivalenol-3-glucoside (Berthiller et al. 2011).

Acknowledgements.- To Dra. Raquel Rubia Rech for technical assistance with photography.

\section{REFERENCES}

Alda J.L., Sallis E.S.V., Nogueira C.E.W., Soares M.P., Amaral L., Marcolongo-Pereira C., Frey Jr F. \& Schild A.L. 2009. Intoxicação espontânea por Baccharis coridifolia (Compositae) em equinos no Rio Grande do Sul. Pesq. Vet. Bras. 29:409-414.

Barros C.S.L. 1998. Livestock poisoning by Baccharis coridifolia, p.569572. In: Garland T. \& Barr A.C. (Eds), Toxic Plants and Other Natural Toxicants. CAB International, Wallingford.

Berthiller F., Krska R., Domig K.J., Kneifel W., Juge N., Schuhmacher R. \& Adam G. 2011. Hydrolytic fate of deoxynivalenol-3-glucoside during digestion. Toxicol. Lett. 206:264-267.

Busam L. \& Habermehl G.G. 1982. Accumulation of mycotoxins by Baccharis coridifolia: a reason for livestock poisoning. Naturwissenschaften 69:392-393.

Driemeier D., Cruz C.E.F. \& Loretti A.P. 2000. Baccharis megapotamica var. weirii poisoning in Brazilian cattle. Vet. Human Toxicol. 42:220-221.

Duncan W.H., Piercy P.L., Feurt S.D. \& Starling R. 1957. Toxicological aspects of southeastern plants. II. Compositae. Econ. Bot. 11:75-85.

Everist S.L. 1981. Poisonous Plants of Australia. Angus and Robertson, Sidney, p.160-161.

Fettman M.J. 2006. Fluid and electrolyte metabolism, p.329-352. In: Thralll A.M. (Ed.), Veterinary Hematology and Clinical Chemistry. Blackwell Publishing, Ames.

Greene C.E. \& Prescott J.F. 2006. Streptococal and other gram-positive bacterial infections, p. 302-315. In: Greene C.E. (Ed.), Infectious Diseases of the Dog and Cat. $3^{\text {rd }}$ ed. Saunders Elsevier, St Louis.

Habermehl G.G., Busam L., Heydel P., Mebs D., Tokarnia C.H., Döbereiner J. \& Spraul M. 1985. Macrocyclic trichothecenes: cause of livestock poisoning in the Brazilian plant Baccharis coridifolia. Toxicon 23:731745.

Jarvis B.B. 1992. Macrocyclic trichothecenes from Brazilian Baccharis species: From microanalysis to large-scale isolation. Phytochem. Anal. 3:241-249

Jarvis B.B., Mokhtari-Rejali N., Schenkel E.P., Barros C.S.L. \& Matzenbacher N.I. 1991. Trichothecene mycotoxins from Brazilian species. Phytochemistry 30:789-797.

Jarvis B.B., Midiwo J.O., Bean G.A., Aboulnasr M.B. \& Barros C.S.L. 1988. The mistery of trichothecene antibiotics in Baccharis species. J. Nat. Prod. 51:736-744.

Jarvis B.B., Wang S., Cox C., Rao M.M., Philip V., Varaschin M.D. \& Barros CSL. 1996. Brazilian Baccharis toxins: Livestock poisoning and isolation of macrocyclic trichothecene glucosides. Nat. Toxins 4:58-71.

Kupchan S.M., Streelman D.R., Jarvis B.B., Dailey R.G. \& Sneden A.T. 1977. Isolation of potent new antileukemic trichothecenes from Baccharis megapotamica. J. Org. Chem. 42:4221-4225.

Marsh C.D., Clawson A.B. \& Eggleston W.W. 1920. Baccharis pteronioides as a poisonous plant of the Southwest. J. Am. Vet. Med. Assoc. 57:430434 .

Morris D.D. 2002. Alterations in the clotting profile, p.434-439. In: Smith B.P. (Ed.), Large Animal Internal Medicine. $3^{\text {rd }}$ ed. Mosby, St Louis.

Mosier D.A. 2011. Vascular disorders and thrombosis, p.60-88. In: Zachary J.F. \& McGavin M.D. (Eds), Pathologic Basis of Veterinary Disease. $5^{\text {th }}$ ed. Elsevier, St Louis.

Nielsen K.F., Månsson M., Rank C., Frisvad J.C. \& Larsen T.O. 2011. Dereplication of microbial natural products by LC-DAD-TOFMS. J. Nat. Prod. DOI: $10.1021 / \mathrm{np} 200254 \mathrm{t}$.

Olivera-Filho J.C., Carmo P.M.S., Lucena R.B., Pierezan F. \& Barros C.S.L. 
2011. Baccharis megapotamica var. weirii poisoning in water buffaloes (Bubalus bubalis). J. Vet. Diagn. Invest. 23:610-614.

Pedroso P.M.O., Bandarra P.M., Feltrin C., Gomes D.C., Watanabe T.T.N., Ferreira H.H. \& Driemeier D. 2010. Intoxicação por Baccharis megapotamica var. weirii em ovinos. Pesq. Vet. Bras. 30:403-405.

Rissi D.R., Rech R.R., Fighera R.A., Cagnini D.Q., Kommers G.D. \& Barros C.S.L. 2005. Intoxicação espontânea por Baccharis coridifolia em bovinos. Pesq. Vet. Bras. 25:111-114.

Rizzo I., Varsavky E., Haidukowski M. \& Frade H. 1997. Macrocyclic trichothecenes in Baccharis coridifolia plants and endophytes and Baccharis artemisioides plants. Toxicon 35:753-757.

Rozza D.B., Raymundo D.L., Corrêa A.M.R., Seitz A.L., Driemeier D. \& Colodel E.M. 2006. Intoxicação espontânea por Baccharis coridifolia (Compositae) em ovinos. Pesq. Vet. Bras. 26:21-25.
Smith., B.P. \& Magdesian K.G. 2002. Alterations in the alimentary and hepatic function, p.102-122. In: Smith B.P. (Ed.), Large Animal Internal Medicine. $3^{\text {rd }}$ ed. Mosby, St Louis.

Stegelmeier B.L., Sani Y. \& Pfister J.A. 2009. Baccharis pteronioides toxicity in livestock and hamsters. J. Vet. Diagn. Invest. 21:208-213.

Tokarnia C.H. \& Döbereiner J. 1975. Intoxicação experimental em bovinos por "mio-mio" Baccharis coridifolia. Pesq. Agropec. Bras. 10:79-97.

Tokarnia C.H., Peixoto P.V., Gava A. \& Barros C.S.L. 1992. Intoxicação experimental por Baccharis megapotamica var. megapotamica e var. weirii (Compositae) em bovinos. Pesq. Vet. Bras. 12(1/2):19-31.

Varaschin M.S. \& Alessi A.C. 2003. Poisoning of mice by Baccharis coridifolia: an experimental model. Vet. Human Toxicol. 45:42-44.

Varaschin M.S., Barros C.S.L. \& Jarvis B.B. 1998. Intoxicação experimental por Baccharis coridifolia (Compositae) em bovinos. Pesq. Vet. Bras. 18:69-75. 